FACTA UNIVERSITATIS

Series: Physical Education and Sport, Vol. 18, No 1, 2020, pp. 159 - 167

https://doi.org/10.22190/FUPES200116013A

Research article

\title{
PHYSICAL ACTIVITY OF ADULTS DURING GREEK TRADITIONAL DANCE AND TENNIS SESSIONS
}

\author{
UDC 796.015 \\ 796.083
}

\section{Danai Anastasopoulou, Fotini Venetsanou, Maria Koutsouba}

School of Physical Education and Sport Science,

National and Kapodistrian University of Athens, Athens, Greece

\begin{abstract}
Physical Activity (PA) is connected with many health benefits and leads to a better quality of life. However, the modern way of life imposes such high levels of sedentary behaviours that physical inactivity is among the key risk factors for mortality. People's participation in active recreational and/or exercise programmes that increase the levels of $P A$ seems imperative if their health is to be enhanced. The aim of this study was to examine the potential differences between the PA offered by Greek Traditional Dance (GTD) and Tennis to adult participants. One hundred and two adults, aged 20 to 76 years, members of GTD (n=57) and Tennis (n=45) clubs, volunteered to participate in the study. The PA gathered during GTD or Tennis was recorded during two randomly selected sessions with Omron 720 pedometers. A multivariate analysis of variance (MANOVA) was computed on the participants' total steps (TS) and aerobic steps (AS). Statistically significant differences were found between GTD and Tennis in $T S\left(F_{1,100}=35.18, p<.001, \eta^{2}=.26\right)$ in favour of GTD, but not in $A S\left(F_{1,100}=.87, p=.35, \eta^{2}=.009\right)$. It can be concluded that GTD sessions offer higher levels of ambulatory activity than Tennis. However, taking into account both the recommendations of daily $P A$ for adults $(\geq 10.000$ steps/day) and the finding of previous studies reporting $P A$ accumulated during various recreational/sport activities, it appears that both GTD and Tennis can significantly help people achieve satisfactory PA levels.
\end{abstract}

Key words: Recreational Activity, Pedometers, Health

\footnotetext{
Received January 16, 2020/ Accepted April 14, 2020

Corresponding author: Fotini Venetsanou

School of Physical Education and Sport Science, National and Kapodistrian University of Athens, 41, Ethnikis

Antistaseos str., 17237 Daphne, Athens, Greece

Phone: + 302107276032 •E-mail: fvenetsanou@phed.uoa.gr

() 2020 by University of Niš, Serbia| Creative Commons License: CC BY-NC-ND
} 


\section{INTRODUCTION}

It is well known that regular participation in Physical Activity (PA) offers several health benefits, including muscular and cardiorespiratory fitness improvement; bone and functional health enhancement; stress and depression reduction, and significantly contributes to the improvement of the quality of life (Word Health Organization-WHO, 2019). According to WHO (2010), a healthy adult aged 18 to 64 years old is considered as physically active, only if he/she manages to accumulate 150 minutes of moderate-intensity PA throughout the week, or 75 minutes of vigorous intensity throughout the week, or a combination of them. Trying to find ways to motivate people to be physically active, researchers translated the aforementioned PA guidelines into steps/day equivalents, since pedometers are inexpensive motion sensors that can be easily used to assess PA (TudorLocke \& Bassett, 2004, Cvejić, Buišić, Mitrović, \& Ostojić, 2019). Thus, an individual is thought of as physically active when he/she accumulates 10000 steps or more per day, whereas those who take more than 12000 steps/day are characterized as "highly active" (Tudor-Locke \& Bassett, 2004).

On the contrary, physical inactivity is strongly connected to noncommunicable diseases and obesity (International Society for Physical Activity and Health, 2017; WHO, 2018), constituting a leading risk factors for death (WHO, 2018). People who are insufficiently active have a $20 \%$ to $30 \%$ increased mortality risk compared to sufficiently active people (WHO, 2018). Some years ago, WHO member states, taking into account the fatal negative consequences of physical inactivity on people's health and quality of life, committed to a 10\% reduction of insufficient PA by 2025 (WHO, 2013). Nevertheless, it seems that no progress in achieving the above goal has happened so far (Guthold, Stevens, Riley \& Bull, 2018). The high percentage $(27.5 \%)$ of people worldwide being inactive that was revealed in a recent study (Guthold et al., 2018) can be attributed to several sedentary behaviors that prevail in several aspects of daily life, like occupation; transport; leisure time. Greece is a country with a high prevalence of both physical inactivity $(30.0 \%-39.9 \%$ for men and 40.0\%-49.9\% for women; Guthold et al., 2018) and obesity (in people older than 16, overweight $=43.4 \%$ and obese $=11.6 \%$; Hellenic Statistical Authority, 2018).

It seems imperative that both global and national policies aiming at enhancing people's active transportation and participation in free or organized PA should be implemented if public health is to be safeguarded. Considering organized PA, several researchers maintain recreational exercise programmes, like aerobic gymnastics (Chatzigianni, Monastiridi, Katartzi, \& Arabatzi, 2017; Rangan et al., 2011), basketball (Lynch, Corbin, \& Sidman, 2009), resistance exercise (Rangan et al., 2011), and dance (Argiriadou et al., 2013a) can significantly contribute to the increase of total daily PA. In this sense, the assessment of the amount of PA that different active recreational activities offer to participants would provide valuable information in order for those activities to be evaluated as a means of PA promotion. In Greece, two of the most popular active recreational activities are Greek traditional dance (GTD) and Tennis, with several participants in a wide age range (Argirou \& Spinos, 2017).

The aim of the present study was to examine the potential differences between the PA offered by GTD and Tennis to adult participants. 


\section{METHODS}

\section{Participants}

One hundred and two adults (51 men, 51 women) aged 20-76 volunteered to participate in the study. Among them, 57 (23 men, 34 women) took part in Greek Traditional Dance (GTD) sessions and 45 (28 men, 17 women) in Tennis sessions organized by respective clubs in Athens, Greece, one or two times per week. All of them had at least one year of experience. Before their participation in the study, all the aforementioned adults were informed in detail about the aim and the procedures of the study, and provided their written consent.

\section{Instruments}

Walking Style Pro HJ-720IT-E2 Omron pedometers were used to record ambulatory activity during GTD and Tennis sessions. This model records steps when placed vertically, horizontally or upside down, due to its piezoelectric sensors that use multi-position measurement technology, and has been found to accurately record adults' ambulatory activity (Giannakidou et al., 2012). According to their manual, Omron 720 pedometers can provide information about the (a) steps taken, (b) distance, (c) time, (d) calories and (e) fat volume during walking or jogging. Regarding steps, Omron 720 pedometers give information about the total count of steps (TS) taken and also aerobic steps (AS, counted when walking more than 60 steps/minute and more than 10 minutes successively). In the present study both TS and AS were used.

\section{Demographic characteristics}

The demographics of participants were collected through a questionnaire, which consisted of items gathering information about the (a) age, (b) gender, (c) years of participation in GTD or tennis, and (d) years of participation in sports or recreational activities.

\section{Procedures}

First, an informative meeting was held in tennis and dance clubs, in which the first author informed the club members about the purpose and the procedure of the study, and guaranteed that their participation would be anonymous and voluntary. At the end of this meeting, written consent forms for participation were given to the club members, who had to fill them out and sign them. One week after the first meeting, the authors visited each club again two times in order to record PA during two 60-min randomly selected sessions. Each participant was given a pedometer five minutes before the beginning of the session and wore it on his/her right hip; at the end of the session, the pedometers were removed. Moreover, at the end of the first measurement, the participants filled out a demographic questionnaire. No instructions had been given to the teachers/coaches about the content of their session. 


\section{Statistical Analysis}

First, the average ambulatory activity of each participant during two GTD and tennis sessions recorded were computed. At a preliminary level, potential differences between the ambulatory activity of males and females within each activity group were investigated, using a t-test. Since no statistically significant differences were detected, the males' and females' data were merged. Then, a multivariate analysis of variance (MANOVA) was computed on the participants' TS and AS to investigate the potential difference between tennis and GTD in the ambulatory activity gathered. Statistical analyses were performed with the use of the IBM SPSS Statistics 25.0 and the alpha level was set at 0.05 .

\section{RESULTS}

Table 1 provides descriptive statistics aggregated by gender and recreational activity, for age and ambulatory activity. The t-test performed on average steps of men and women separately for GTD and Tennis, showed that there is no statistically significant association between the participants' gender and their ambulatory activity either during a GTD $(\mathrm{t}=1.55$, $\mathrm{p}=.13)$ or a Tennis session $(\mathrm{t}=.43, \mathrm{p}=.67)$.

Table 1 Descriptive statistics for age, total steps, and aerobic steps

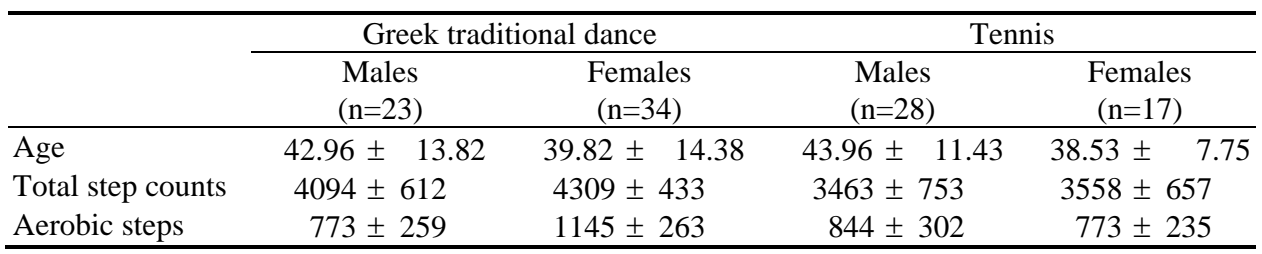

The MANOVA that was applied on the participants' total and aerobic steps revealed that the multivariate results were significant for the recreational activity group (Pillai's trace $=.29$, $\mathrm{F}=19.83, \mathrm{p}<.001, \eta^{2}=.29$ ). Subsequent univariate analyses indicated that there were statistically significant differences between Tennis and GTD in the total steps $\left(F_{1,100}=35.18, p\right.$ $\left.<.001, \eta^{2}=.26\right)$, with GTD having higher scores than Tennis, but not in aerobic ones $\left(\mathrm{F}_{1,100}\right.$ $\left.=.87, \mathrm{p}=.35, \eta^{2}=.009\right)$.

\section{DISCUSSION}

Participation in active recreational and exercise programmes are thought to contribute to the enhancement of PA levels (Lynch et al., 2009; Rangan et al., 2011; Argiriadou et al., 2013a; Chatzigianni et al., 2017) and promote health and quality of life (WHO, 2018). Evidence suggests that step-based metrics used in accordance to the federal PA guidelines facilitate individuals' ability to comprehend and achieve a physically active lifestyle (TudorLocke \& Aguiar, 2019). The aim of this study was to examine the ambulatory activity gathered by adults who participate in GTD and Tennis programmes. 
The results showed that the participants in 60-min GTD sessions accumulated on average 4222 steps, whereas those who participated in 60-min Tennis sessions presented statistically significantly lower average step counts ( 3499 steps). This may be due to the fact that in GTD, the participants should execute specific movements that each dance consists of, whereas in a Tennis session each participant decides on his/her own how active he/she will be (covering a small or a big part of the court). Regarding AS, the differences between the two activities were statistically insignificant, although participants in GTD gathered more AS than those who took part in Tennis. A possible explanation for that finding is that a GTD session may contain both fast and slow dances. Thus, during a session with a higher percent of slow dances, the frequency of steps taken would not be sufficient enough in order for those steps to be recorded as AS. The step counts of the GTD sessions in this study were slightly lower than that revealed (4721 steps) in the study of Argiriadou and colleagues (2013a), in which a GTD session of the same duration took place. However, lower PA was recorded in a previous study, in which a 30-min continuous walking (3411 steps/session) and a 70-min exercise programme, consisting of resistance and aerobic exercise (3729 steps/session), were implemented (Tudor-Locke, Jones, Myers, Paterson, \& Ecclestone, 2002). It seems that GTD, although not a sport activity, offers higher PA levels than other programmes. This finding, in conjunction with those of previous studies showing that GTD also contributes to the participants' quality of life (Argiriadou et al., 2013b; Bougiesi, Zisi, Gregoriou, \& Pollatou, 2011), and supports that GTD can be treated as a valuable PA.

In the present study, participants' daily step counts were not measured; thus, it was not possible to examine PA differences between days with and without GTD or Tennis. Nevertheless, in previous studies the daily ambulatory activity of people aged 31 to 65 (8408 steps; Lynch et al., 2009) or older than $60=$ [6480 steps (Tudor-Locke et al., 2002); 6250 steps (Hernandes et al., 2013)], when they did not participate in PA programmes, has been found to be lower than recommended. Moreover, several researchers have shown that more PA is accumulated on days including an organized PA programme than on those without (Tudor- Locke et al., 2002; Lynch et al., 2009), refuting in that way the PA compensation concept, according to which a decrease in PA follows increased PA (Lynch et al., 2009). From the above mentioned, it can be assumed that both GTD and recreational Tennis can significantly contribute to the achievement of the 10000 steps/day recommendation (TudorLocke et al., 2004).

The results of this study should be interpreted in the prism of its limitations that require discussion. To begin with, the relatively small sample size does not allow for result generalization. Moreover, as it was earlier reported, only the ambulatory activity gathered during GTD and Tennis sessions was measured and not that of the rest day; thus, a clear picture of the participants' total daily activity on days with and without GTD or Tennis has not been obtained. Furthermore, although the pedometers provide information about steps taken when walking more than $60 \mathrm{steps} / \mathrm{min}$ and more than 10 minutes successively and called them aerobic, this information is not sufficient enough for describing activity intensity. Nevertheless, despite its limitations, this study adds information for the PA offered through two popular recreational activities and shows that they both contribute to the PA enhancement. However, undoubtedly, further research is needed if sound conclusions are to be drawn. Studies examining PA gathered in a variety of recreational activities could provide valuable information that will help people select the best activity for them. 


\section{CONCLUSION}

GTD sessions seem to offer higher ambulatory activity than Tennis sessions; however, both recreational activities provide their participants with a valuable amount of PA. Although, as it has already been mentioned, further research is needed to obtain sound conclusions about the contribution of each recreational/sport activity to public health, participation in active recreational or exercise programmes should be encouraged and promoted if physical inactivity of people today is to be reduced.

\section{REFERENCES}

Argiriadou, E., Mountakis, C., Konstadinakos, P., Zakas, A., Mavrovouniotis, F., \& Mavrovounioti, C. (2013a). The physiological effects of Greek traditional dances on mood states of middle-aged people. Sport und Präventivmedizin, 43(2), 6-11.

Argiriadou, E., Mountakis, C., Konstantinakos, P., Zakas, A., Mavrovouniotis, F., \& Mavrovounioti, C. (2013b). The effect of a single bout of Greek dances on subjective health of middle-aged people. Journal of Physical Education and Sport, 13(2), 177-183.

Argirou, C., \& Spinos, S. (2017). I epidrasi diaforetikon programmaton askisis stin psichologiki ygeia-evexia enilikon (The effect of different exercise programmes on psychological health-wellness in adults). Unpublished bachelor thesis, Athens: School of Physical Education and Sport Science, National and Kapodistrian University. In Greek

Bougiesi, M., Zisi, B., Gregory, S., \& Pollatou, E. (2011). Greek folk dance systematic participation affects quality of life in young and middle age. Inquiries in Sport \& Physical Education, 9(2), 134-143.

Chatzigianni, I., Monastiridi, S., Katartzi, E., \& Arabatzi, F. (2017). Adults' physical activity assessment using pedometers in different types of indoorfitness activities. Book of abstracts of the 25th Anniversary International Congress on Physical Education \& Sport Science, May 19 ${ }^{\text {th }}-21$ th, 2017, (pp. 168), Komotini: School of Physical Education and Sport Science, Democritus University of Trace

Cvejić, D., Buišić, S., Mitrović, N., \& Ostojić, S. (2019). Aerobic activity of students during physical education fitt classes. Facta Universitatis Series Physical Education and Sport, 16(3), 515-524.

Giannakidou, D.M., Kambas, A., Ageloussis, N., Fatouros, I., Christoforidis, C., Venetsanou, F., \& et al. (2012). The validity of two Omron pedometers during treadmill walking is speed dependent. European Journal of Applied Physiology, 112(1), 49-57.

Guthold, R., Stevens, G.A., Riley, L.M., \& Bull, F.C. (2018). Worldwide trends in insufficient physical activity from 2001 to 2016: a pooled analysis of 358 population-based surveys with 1. 9 million participants. The Lancet Global Health, 6(10), e1077-e1086.

Hellenic Statistical Authority (2018). Erevna gia to ikogeniako isodima kai tis sinthikes zois; Etos (2017Survey of household income and living conditions: Year 2017). Retrieved December 10, 2019 from the World Wide Web:

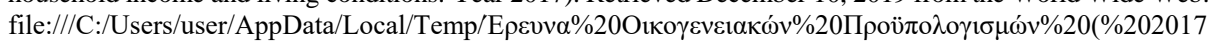
\%20).pdf. In Greek

Hernandes, N.A., Probst, V.S., Silva Jr, R.A.D., Januário, R.S., Pitta, F., \& Teixeira, D.C. (2013). Physical activity in daily life in physically independent elderly participating in community-based exercise program. Brazilian Journal of Physical Therapy, 17(1), 57-63.

International Society for Physical Activity and Health. (2017).The Bangkok declaration on physical activity for global health and sustainable development. British Journal of Sport Medicine, 51(19), 1389-1391.

Lynch, K.B., Corbin, C.B., \& Sidman, C.L. (2009). Testing compensation: does recreational basketball impact adult activity levels?. Journal of Physical Activity and Health, 6(3), 321-326.

Rangan, V.V., Willis, L.H., Slentz, C.A., Bateman, L.A., Shields, A.T., Houmard, J.A., et al. (2011). Effects of an 8-month exercise training program on off-exercise physical activity. Medicine and Science in Sports and Exercise, 43(9), 1744.

Tudor-Locke, C., \& Aguiar, E.J. (2019). Toward comprehensive step-based physical activity guidelines: Are we ready?. Kinesiology Review, 8(1), 25-31.

Tudor-Locke, C., \& Bassett, D.R. (2004). How many steps/day are enough?. Sports Medicine, 34(1), 1-8.

Tudor-Locke, C., Jones, G.R., Myers, A.M., Paterson, D.H., \& Ecclestone, N.A. (2002). Contribution of structured exercise class participation and informal walking for exercise to daily physical activity in community-dwelling older adults. Research Quarterly for Exercise and Sport, 73(3), 350-356. 
World Health Organization-WHO (2019). Global action plan on physical activity 2018-2030: More active people for a healthier world. Geneva: World Health Organization.

Word Health Organization-WHO (2013). Global action plan for the prevention and control of noncommunicable diseases 2013-2020: More active people for a healthier world. Geneva: World Health Organization.

World Health Organization-WHO (2010). Global recommendations on physical activity for health. Geneva: World Health Organization.

\section{FIZIČKA AKTIVNOST ODRASLIH TOKOM GRČKOG TRADICIONALNOG PLESA I TENISA}

Fizička aktivnost (FA) ima zdravstvene prednosti $i$ vodi ka boljem kvalitetu života. Međutim, savremeni način života nameće visok nivo sedentarnog ponašanja da je fizička neaktivnost među ključnim faktorima rizika smrtnosti. Učešće ljudi u aktivnim programima za rekreaciju i/ili vežbanje koji povećava nivo FA čini se imperativom u poboljšanju zdravlja. Cilj ovog istraživanja bio je da se ispitaju potencijalne razlike između FA koje odraslim učesnicima nude Grčki tradicionalni ples (GTD) $i$ Tenis. Stotine dve odrasle osobe, starosti od 20 do 76 godina, članovi GTD $(n=57) i$ teniskih $(n=45)$ klubova, dobrovoljno su učestvovali u istraživanju. FA tokom GTD-a i Tenisa utvrđena je Omron 720 pedometrima tokom dve nasumično odabrane sesije. Multivarijantna analiza varijance (MANOVA) izračunata je na ukupnim koracima učesnika (TS) i aerobnim koracima (AS). Statistički značajne razlike utvrđene su između GTD-a i tenisa u TS-u $(F 1,100=35.18, p<.001, \bar{e} 2=.26)$ u korist GTD-a, ali ne i u AS-u $(F 1,100=.87, p=.35, \bar{e} 2=.009)$. Zaključuje se da GTD nudi veći nivo ambulantne aktivnosti od tenisa. Međutim, uzimajući u obzir i preporuke dnevne FA za odrasle (>10.000 koraka/dan) i nalaz prethodnih istraživanja o FA prikupljenih tokom različitih rekreativnih/sportskih aktivnosti, čini se da $i$ GTD i tenis mogu značajno da pomognu ljudima da postignu zadovoljavajući nivo FA.

Ključne reči: rektreativna aktivnost, pedometri, zdravlje 

